RESEARCH ARTICLE

\title{
The Different Existing Patterns of Landholding System that Determine the Mode of Agrarian Change: A Case Study of Tangkhul Nagas
}

\section{W. S. Machutmi}

Department of Sociology, Delhi School of Economics, University of Delhi, India

\begin{abstract}
:
This paper focuses on the way tribal communities conceptualised the importance of land, and the different type of landholding pattern system that has affected this agricultural community. There are various intricacies involved in defining the ownership of land: It includes who should own the land and to whom the land should be given out in the form of leasing out for a cultivation purpose? For example, the so called "clan land" should be confined to the clan not outside. This paper, therefore, is an attempt to look at various customs and rituals which have an influence upon the various kinds of landholding ownership system and to make a specific case study of Tangkhul Nagas, situated in the Ukhrul district of Manipur, Northeast India.
\end{abstract}

Keywords: Agricultural community, private land, clan land, community land, modernity, Christianity

\section{Introduction}

The existing patterns of landholding system have been responsible for the changes that is introduced in this tribal community. The impact of modernity that has come along with Christianity has inculcated the idea of owning land. Thus, land ownership began to emerge. The paper intensively engages with the circulation of landholding system and ask whether rites and rituals practices in the past continue to have a holdover at present. In the past, the ownership of land involved performance of series of rites and rituals. At present, the rites and rituals are no longer practiced. In order to make this study possible, the fieldwork was done in Teinem village, between July 2016 and March 2019. The time taken for this research work is almost two years as the entire fieldworks of the research work for the whole writing of thesis are all included. The research work is based on qualitative method which employed personal interviews, group interviews, and focus group interviews.

\section{Literature Review}

The Tangkhul Naga community is known for its egalitarianism since time immemorial. As a result of modernity, however, the idea of land ownership began to emerge in a more visible form. A new mode of landholding system began to evolve. The assertion of right to ownership of land by the community, clan and individual has become prominent. In the newly emerged 
landholding system, a village Chief no longer has the right to interfere concerning the individual and clan land except selling land to a person from a different village.

In order to contextualize the Tangkhul Naga community landholding system, I have examined some of the landownership systems in different parts of India inhabited by the tribal communities. As it is known in the North Cachar hills district of Assam, according to Sikidar (1990),

The village head is the custodian of the village land; however, overall, the land is controlled by the district council. Villagers are free to select a suitable land in their village land for shifting cultivation, but cannot claim ownership, without the consent of the village headman. Moreover, flat lands for wet or permanent cultivation are leased and settled annually at a given rate to the villagers by the district council. The annual leaseholder is also devoid of any right of inheritance and transfer without the prior approval of the district council authority. There is also periodic lease of thirty years, in some pockets of settled areas like Haflong town, Maibong, Harangajao and Langtings. (p.14)

Tiwari \& Shahi (1995) said that, "The pattern of land ownership plays an important role in land use and agricultural development and planning. For a better understanding of land ownership, related laws give an insight into the problems faced by our present-day society" (pp. 61-78).

The right of ownership differs from one state to another in India. The study conducted in 1981 in Jalpaiguri and other districts in Bengal (India) is worth mentioning. In these districts, it is found that the land transferred in the form of sale and purchase did not always go into the hands of non-cultivators. Those transferred land also went to the cultivator. The rich or well- to- do cultivators in such a situation began to acquire more and more lands. Despite this development the land remains intact, as the method of cultivation did not change (Mitra, 1953).

The right to property affects the growth of economy in several ways. Firstly, it gives security to households and individuals to invest, and often provides accessibility to credit. It also gives assurance as a substitute in the event of shocks. Secondly, in the traditional method of agriculture, the operation of distribution of land affects the output. It is also believed that unequal land distribution is a result of low production. The ability to make productive use of land will depend on land policies. Thirdly, in order to secure the well-defined land, rights are key for household asset, ownership, productive development, and market functioning (Deininger, 2003). Bruce Russett (1964) stated that,

Merle Kling, for example, blames political instability in Latin America on the extreme concentration of economic bases of power in what he terms "colonial economics." Land ownership he says, is so heavily concentrated that not individual not already possessing great tract of agricultural land can reasonably hope to achieve wealth through farming. (p. 33)

Datye \& Diddee (1981) critically examined the relationship between the landholding system and agricultural practices in Pune (one of the districts in Uttar Pradesh, India) in terms of the trends in changes made to the level of production. Finally, they have come to a conclusion that the nature of landholding system has an adverse effect upon the agricultural production in this district. The 
prominent sociologist Smith Lynn (1967) states, "That the size of agricultural holdings, the extent to which the ownership and control is either concentrated in a few hands or widely distributed among those who live by cultivating soil, is the most important single determinant of the welfare of the people in rural district" (p. 8).

\section{Discussion}

During the colonial period, the king of Manipur remained as the head of the state, and the hills were administered by the political agent. The British administration at first believed in the policy of laissez-faire with regard to the tribal. This measure was adopted for the convenience of administration. Another reason was the British desire to keep the tribal people away from the political infection. (Ghosh, 1987, p. 1). Further, it has led to shortage of land. The existing law has to be updated instead of being replaced by another system that can weaken them as a community. Such modern input has adversely affected the tribal people and their customs and cultures. Such modern inputs become negative when they are superimposed on tribal tradition with no preparation for interface between the two systems (National Sample Survey Organisation, 1999).

One of the interviewees asserted "that the land occupied by the Tangkhul Nagas is a virgin land no one had inhabited when the Tangkhul Nagas came to occupy this land. The land is life for the tribal." The Tangkhul Nagas, by tradition, had deep respect owed to the land since time immemorial and such affection to land had passed on from one generation to another. Malinowski (1965) stated that "Land tenure must be conceived in a more comprehensive manner: it is the relationship of man to soil in the widest sense; that is, in so far as it is laid down in native law and customs", (p. 319).

The ancestors revered the possession of land by performing various rituals during festivals showcasing the richness of their traditional culture. As narrated by one of the elderly people before Christianity spread, the ancestors were aware of the existence of God known as "Ara."2 People worshipped him, as he was considered a good God and benevolent God. Then, the lesser gods were evil bent on destroying crops and disturbing human beings. People tried to pacify them by offering chicken and brewed local wine. In the case of somebody getting sick, without offering them Chicken or animals, it was believed that the person would never recover completely from sickness. It is believed that God gifted land to the Tangkhul Nagas. As a saying goes, "land is older than men and therefore, do not make fun of land." The land, that is occupying today is a virgin land. No one had inhabited it; they were the first one to have occupied this land. No history has revealed somebody's garden was forcibly taken away without any reason and no cases of the owner leaving the place voluntarily or willfully. ${ }^{3}$

All these kinds of rituals and believes which were strongly upheld and sanctified by the ancestral began to exist in a loose manner as a result of Christianity that has come along with modernity. This has led to a change in the landholding system, which has introduced different kinds of land ownerships.

\footnotetext{
${ }^{1}$ Interview conducted on August, 2016

2 It is known as the greatest or the 'supreme God' during the ancestral days.

${ }^{3}$ Interview conducted on April 8, 2016
} 


\subsection{Classification of Different Landholding System and its Usage in the Past and Changes that Have Taken Place}

During the ancestral days, majority of the land ownership was based on community land although, there were private ownership of lands also prevailed. Majority of them practiced or engaged in shifting cultivation (traditional method of cultivation). The cultivation was confined simply for a family consumption only. They were also known for self -sufficiency in terms of production. The idea of selling and buying or commercialization was not known to them. Whatever they produced they shared each other in the form of exchange and gift. However, they had a strong attachment on land and thus performed various rites and rituals. ${ }^{4}$

The idea of territory or land is everywhere in societies. According to Morris \& Marsh (1988) "Territoriality is such a deeply ingrained aspect of human life that we tend to assume that it is something we have acquired during our evolution" (p. 27).

The territory of the village is considered one of the most important parameter for determining the limit of the economic activities. One villager cannot cross over to another village with an intention to do farming, jhumming ${ }^{5}$ and other related economic activities except hunting and fishing (Shimray, 2007). The restriction of crossing over from one village to another involved a certain amount of acknowledgement. For example, if an animal crosses another village while hunting, that particular village is paid a piece of meat in the form of acknowledgement of ownership. The Tangkhul customary laws determine the usage of land. ${ }^{6}$

The various Tangkhul authors' classifications of village land use system can be examined as follows: According to Ruivah (1987) "Village land use could be categorized as (i) Village settlement area, (ii) Woodland, the nearest forest to the village settlement area, (iii) Jhum- area, (iv) Public or village community land, and (v) Sedentary terraced paddy field" (pp.54-64). According to Shimray (2007) There are different forms of land use and ownership patterns. One can broadly categorise them into three categories: (i) village settlement area, (ii) Community and Clan land and (iii) Forest" (p.102).

The tribes in Manipur have a different pattern of landholding systems. The Thadou Kuki, has a village chief who has the sole authority on land and the Naga has a nominal head, who is the village Chief, but he does not have an authority over individual and clan lands. There are different types of landholding by the Nagas. Some tribes have three and some have two types of landholding systems. All of the three tribes in Manipur practice three types of landholding systems: Tangkhul Nagas, the Mao Nagas, the Rongmei Nagas and the Poumei Nagas. The Maram and Maring tribes follow two types of landholding system (Binodini Devi, 2006).

The neatly tied existing structure of private landholding system has made it difficult for agrarian change. For example, the individual has the authority to give permission or refuse the proposed government projects to be implemented. This has made the government difficult to negotiate various groups of people who have the authority of ownership of land. Therefore, in

\footnotetext{
${ }^{4}$ Interview conducted on April 8, 2016

${ }^{5}$ This term refers to the traditional method of cultivation practice by the tribal communities in Manipur, Northeast India

${ }^{6}$ Interview conducted on April 8, 2016
} 
such a situation, the government has resorted to forceful kinds of land acquisition. Regarding the land ownership or holding system, Gangmumei (1986) concluded by saying that,

The landholding system has changed and with the possessory rights vested in the individuals to the control of the village land by seven Rampous (owner of the land) with the continuity of the individual's possessory rights, then to the emergence of private land ownership with the development of terrace cultivation, horticulture and wet-land cultivation. But the village council checks the transfer of their lands to the outsiders. The village council regulates the shifting agriculture production activities. (p. 23)

The idea of clan land emerged as a result of modernity. This is followed by the emergence of commercialization, where there is no surplus production. In other words, the word "selfsufficiency" become no longer relevant. As a result of the introduction of new technology, people at present have started abandoning traditional methods of farming and are focusing on new methods of farming. For example, several Tangkhul Nagas villages have started the practice of applying high yielding variety (HYV) in the paddy-field, farm, etc. At present the land has been used for several purposes that include commerce, education, and better standard of living. The form of ownership and usage of lands, therefore, have been produced and reproduced into different forms.

\subsection{Ceremony to Get Entitlement of the Head of the Clan}

The performing of this ceremony involved two big buffaloes killed for feasting. The head of the clan's characteristic is featured by owning a huge land in the village. Unfortunately, due to carelessness, a huge portion of lands were sold to others. The well-known example can be that of the homestead sold to Mr. Vashi, which has a remarkable landmark, as this is the earliest or the first settlement place or a first homestead of Ralengwo (head of the Raleng's clan). In 1962, his father passed away, and his son succeeded him. There was a term called shangsikomkui (gathering of all the three clans: Ramror, Yasing, and Raleng). This occasion was celebrated in his place participated in the feasting by all of the three clans (Raleng, Ramror and Yashing). This was organized after every three years and Ralengwo (the head of the Raleng's clan) was given a head whatever animals they ate in the form of an acknowledgement as the eldest man and the head of all the three clans. Another way to recognize being the eldest was through organizing such a gathering in his place and this is done after seating together with each clan to decide to have such functions. Such occasions were celebrated after every three years. Later on, it was found that Yashing (YS) is celebrating it all alone. When they were with us, they have given us six times the animals head (Pig's head) to the Ralengwo (head of the Raleng's clan). In the beginning, as he was the head of the Ralengwo, he was asked to look after a pig before the feasting ceremony. The pig was later eaten together by all the three clans together. ${ }^{7}$

\subsection{The Peculiarity of the Clan's Landholding System that Determine Agrarian Change}

There are only few Tangkhul villages which follow clan landholding system, Teinem village and Phalee village are a case in point. In Teinem village, the clan by the name Raleng is known for practicing this type of landholding systems and some few years back such clan

${ }^{7}$ Interview conducted on September 28, 18 
landownership stopped to be practiced in the latter mentioned village. Clan ownership of land is still practiced in Anal Khullen, Chakpi- Karong, Lambung, Lamphou- Pasna, and in Chandel Christian, etc., whereas it is no longer practiced in Salluk, Charongching and Tokpaching. Some of the clans in Chandel district have stopped practicing clan land ownership due to the limited availability of land for jhumming (Gangmumei,1985).

The so-called Raleng's clan is known to be one of the earliest inhabitants of this village. They have approximately less than one hundred households altogether. It is not easy to acquire a huge size of land and the title of the head of the clan, which has necessitated the performance of various rites and rituals. The same is with the case of Mr Raleng, the youngest member of the family, who happens to have acquired the title "Ralengwo" (head of the Raleng's clan) as he could have performed all the rites and rituals and have earned this the most respectable titled head of the Raleng's clan. It is believed that they have migrated from Hungpung village, albeit some of them have contested the history of this migration. Unfortunately, at present, one of his immediate siblings had contested the headship of the clan but failed as there was no proof or evidence to support. There is also a story narrated about some members of this clan that it is believed to have been migrated from Phalee village in $1964 .^{8}$

\subsection{The Idea of the Emergence of Raleng's Clan Land}

It is believed to have been around fifty generations ago, the first person among the Raleng's clan to have settled down in Teinem village was Mr Ralengwo (Shokngaleng head of the clan), descended or migrated from Hungpung village. Usually, the earliest settlers or the eldest person had owned a huge size of land in the village. In this way, he had owned land everywhere in this village. Some of them are Lungchong (in the hills) Lungpar (in a place where dry terrace cultivation is widely practice), Kaochao (near the wet-terrace cultivated place), Chipe, Rishim (near the paddy-field of Sirarakhong village), Shangkhaleng (near Phalee village), Khonpaotung (near Sirarakhong village), Pungao (near Sirarakhong village hills side), Khonglang (near Champhung village), Mawot (near one of the locality called Awung dang. Teinem village) Leithon (near Awung dang Cemetary, Teinem village), Lungkhupyi (just near to Ralengwo's homestead), and Shingkuiram (near to Ralengwo's homestead). The land has been preserved carefully in order to trace the generation of one descendant. When the head of the clan failed to own a single piece of land, he was considered a threat. He further, said that in his next generation if he could not have kept or preserved a single piece of land then, that would tarnish the identity of one's clan headman ship. In the case of him, all the Ralengwo land will remain so long as this clan exists. Keeping this in mind, he has decided to initiate such a clan's land preserving steps. His father had told them seriously that "land should not be sold at any cost and the land does not simply belong to him, it belongs to all your clan and your brother and your generations to come and hence should make use of all your land appropriately at any cost." He was told several times by his father and grandfather about the value of preserving land. ${ }^{9}$

The reason behind his youngest brother's succession to the possession of head of the clan is that the elder brother cannot afford to perform the rites and rituals to get the title of the head of

\footnotetext{
${ }^{8}$ Interview conducted on September 28, 2018

${ }^{9}$ Interview conducted on March 14, 2019
} 
the clan. Therefore, the youngest brother had performed all the required rituals and rites involved to get the headship of the clan (Head of the Raleng's clan). As in the past, it is made mandatory to perform such a series of rites and rituals to get the entitlement of the head of the clan. Another reason is that Ralengwo (head of Raleng's clan) did not have a child to taken over the headship. Before he passed away, he had requested his immediate brother (Awukhararleng) to perform the rites and ritual, but he refused, saying that he would not be able to do it. $\mathrm{He}^{10}$ was his father's father (Grandfather). Finally, he had (the younger brother) inherited the Ralengwo (head of the Raleng's clan) by performing all the required rites and rituals. Thereby, he inherited the headship of the Raleng's clan along with all the entitled assets: Land, paddy-field, woodland, and homestead, etc. The eldest one was allowed to maintain certain dignity only by raising a symbolic curved wood while constructing a house depicting that he is the eldest. This is how the actual headship has been passed on to the present Ralengwo (head of the Raleng's clan). ${ }^{11}$

The ceremony of getting entitlement of headship of the clan was concluded with the presentation given to Mr. Raleng (Youngest brother) and he said, "Everything that belongs to the clan (Referring to the Raleng's clan land and the lands that were owned by his eldest brother, who was the head of the Raleng's clan in the past) should be treated as mine." Thus, he was declared the head of the Raleng's clan by presenting traditional shawl as a sign of respect depicting that he is the head of the clan. This ceremony was performed in the presence of all the Raleng's clan members.

\subsection{The Importance of Clan's Land}

During his time, the place that was called 'lungchong, ${ }^{12}$ was sold to Mr Vashi due to financial constraints. The earliest paddy-field for the Ralengwo is 'lungkong, ${ }^{13}$ not 'eikong,' the latter was bought when the former was sold. The interviewee told us that in case the land (farming place) was sold to his non-relatives, it would never return to his clan. With this realization, this realisation, he has sold it to his clan with just Rs.1000/- in 1968. The real value of the clan's land emerged when his owned personal land was sold to his clan. Initially, this idea of clan's land never comes seriously into his mind. This incident makes him, realised that land, should be sold only within the clan and thus the idea of clan's land emerged. You can buy my land with this clan's fund, if incase, it goes out of the clan's land, it will become the permanent land of others. Fortunately, he has sold it to his clan and it becomes the clan's land and his land continues to extend in the form of buying more and more land in the name of the clan till today. ${ }^{14}$

The preservation of such land strengthens the idea of 'we-feelings', which begins to grow stronger when this clan member can own their land in a particular place demarcated as the only clan's land in the village. In 2016, Lungchong Maiphai block or sub-division ${ }^{15}$ began to function. The Manipur state government has asked for a donation of land. One of the members of Raleng's clan was given a permanent State government job in the form of acknowledgement because of the

\footnotetext{
${ }^{10} \mathrm{He}$ refers to the respondent or the interviewee.

${ }^{11}$ Interview conducted on March 14, 2019

12 The first farming place or the mountain of Raleng's clan

13 The first paddy-field of Raleng

${ }^{14}$ Interview conducted on March 14, 2019

${ }^{15}$ The first inaugurated western Tangkhul block situated at Teinem village, Ukhrul District, Manipur
} 
land donation. They have a common water tank; some of them started constructing a house at this demarcated clan's land. Apart from homestead, space kept for all of the members of this clan. They also have set aside the place for farming which is known as the first Raleng's clan mountain. This land has been there since ancestral days, albeit it was not jointly owned by the clan members just as it is at present. This land has been there as Raleng's clan, since they came and settled down into this village. There are thirty-two households altogether owning this clan's land at present. This land has been equally divided among them except for the Ralengwo (head of the Raleng's clan) who is asked to choose whatever portion he wanted. There is a big difference in terms of size with the members of his clan with regard to distribution of land (Raleng's clan land). At present, he (referred to the present head of the Raleng's clan) has chosen the place where the crushing stone engine, is installed at newly created Sub-division Block known as Lungchong Maiphai (situated in the ukhrul district of Manipur, Northeast India) and the landmark is the pond which has permanent water flowing for throughout the year. ${ }^{16}$

One third of the land has been donated to the State Manipur Government for the creation of Lungchong Maiphai Block. The remaining land that is one and a half has been distributed among themselves. Although some members suggested the distribution of everything, he did not allow them, saying that this land should be preserved for the next generations. Out of one third, one is given to the government, another one is divided among themselves and the remaining one is kept for the generations to come. The whole land was distributed into 100/100. After the distribution, they have a planned to divide the remaining equally for the next generations. ${ }^{17}$

The advice given to the member of the clan is that, this land should never be sold outside the clan. In the case of selling to others, the clan in a group should come and rescue the land.

\footnotetext{
${ }^{16}$ Interview conducted on March 14, 2019

${ }^{17}$ Interview conducted on March 14, 2019
} 
Certain

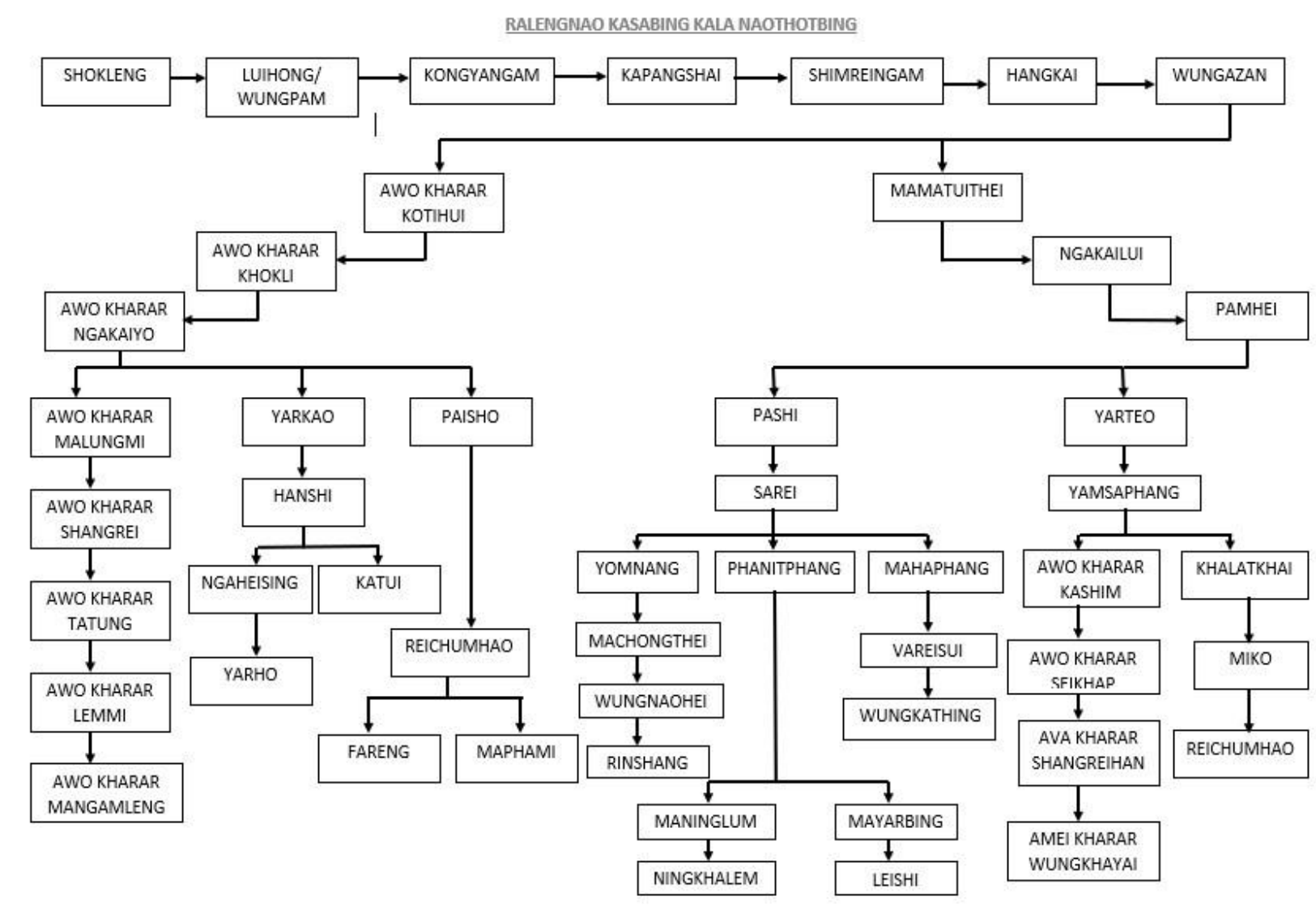

Sources: Table of the Descendants of Raleng's Clan (Teinem village, Ukhrul District, Manipur) compiled by the author

Rules were made to bind all the members of the clan together that, the member should sale the land within the clan only and a strong resolution has been passed in the clan's meetings in which the members unanimously decided to adopt the resolution even in a generation to come. The resolution was passed in 1971. This happened when one of the members of the clan sold his land due to financial problems. This incident has become an eyes opening for the member. The resolution said, again and again, that "if it is to be sold it should be only through the knowledge of the clan." He has sold it to another clan, and when the Lungchong Maiphai, (one of the subdivision blocks in Manipur) started functioning in the village, the value of this land increased necessitating to take steps of preservation in the form of a clan as a whole. In 2002, there was a decision taken again in the clan's meeting that each household should be distributed 100/100 inches; this is how the distribution of land took place for the first time in 2016 according to the decision taken in 2002. To avoid misunderstanding by the next generation, such resolution to distribute land was made. Anything can happen to this kind of arrangement was addressed. In order to safeguard from all these kinds of nuances, the collective clan's decision was taken. ${ }^{18}$

Some of the villagers opposed saying the sole authority should not be given to the head of the Raleng's clan, but it should be collectively owned by the member with equal rights of

${ }^{18}$ Interview conducted on March 18, 2019. 
purchasing and sale. Some of the elderly people suggested that the Ralengwo (head of the Raleng's clan) realized the importance of his clan's existence and thus sold it to his clan. Therefore, others have acknowledged what he did and allowed him to select the portion of his choice of land. At that time, some people from outside the clan were still willing to buy this land then. Due to his farsightedness, he brought back and reserved this land for them. Although some people were willing to pay more than what his clan could have paid. Now some of them have tried to treat him equally as an ordinary member, which is not acceptable. Accordingly, the land was distributed 100/100 per a member and for the Ralengwo it is 400/100. ${ }^{19}$

Some of the heads of clans in the village were deeply impressed by the existence of such a group clan's land and told him that in case such concrete steps initiated, they should be praised. Some people asked, why should the land be owned in the name of clan? Since they want to see that this clan is being divided. There was peace prevailing for several years in this clan. It so happened that when one of his close members got married, the surface of the crisis began to prevail saying that the portion given to Ralengwo is supposed to be his portion. One practical example is that of Rishim (place) when the tree was cut down for firewood consumption. He cleared off the portion belonging to Ralengwo still then and one of his close members proclaimed himself to be the Ralengwo (head of the clan). In this way, the villagers started identifying and investigated the disputed site. On the side of the Teinem, there was a boundary shared with one of his relative eastern sides bordered with the head of the clan of Lk (Langkham) and touched the border with Mr. Vashi's territory. He brought all these witnesses while the opponent could not bring even a single evidence. The particular field-sites were cultivated several times by the Ralengwo. One year, the head of the Raleng's clan father had done a shifting cultivation in this place. The dispute was finally settled down in the Teinem village court, by the village authority in his favour as he offered concrete evidenced. ${ }^{20}$

This village does not have the actual proportionate size of land for farming purposes according to the size of the population. The existing land scenario in this place (Luchong Maiphai, subdivision) is that almost one third of the land is owned by the two clans that are Vashi and Raleng; the latter clan owned a bigger size. When I interacted with some of the respondents ${ }^{21}$ (villagers), it is found that some of them were not allowed to do cultivation in this place, albeit it was allowed to their immediate relatives within a certain period of time without any ownership rights. The situation is that these group of people neither have paddy-field nor enough place to do shifting cultivation and farming. In such a situation, however, the land remained fallow for a long period without leasing out to the needy cultivator, which ultimately resulted in low production due to such existing clan land ownership. In other words, when this Raleng 's clan had enough land to lease out for cultivation, his clan did not do so as they had an agreement that the land is prohibited to be sold outside the clan and should not even be leased out to other clans for farming purposes, which they think is a threat for them. Hence, the idea of the concept of clan land has affected the agricultural system in terms of production. ${ }^{22}$

\footnotetext{
${ }^{19}$ Interview conducted on March 22, 2019.

${ }^{20}$ Interview conducted on March 14, 2019

${ }^{21}$ Interview conducted on March 22, 2019

22 Interview conducted on March 22, 2019
} 
The other two landholding systems that have affected the agriculture systems are community land and individual or private land, which are briefly explained in the abovementioned paragraph. In the community land, the Chief or the Headman and village authority has the ultimate power to decide in which particular place the villagers have to do shifting cultivation and it is decided only on a yearly basis by consulting the eldest man from the village who performs a ritual and accordingly finalize the field-sites for shifting cultivation. During the ancestral days, chicken, rice, and vegetable etc., were given to the Chief or Headman and village authority in the form of acknowledgement or showing the ownership for allowing to do shifting cultivation and collecting firewood. The community land can be used for different purposes: Some are used for farming, collecting firewood, shifting cultivation, constructing houses, the village church, other various buildings construction, and maintaining playground for the villagers. In the beginning, the church homestead of the village was created through a donation to allow the converted Christians to construct their respective houses. But when the population started increasing, in order to protect this land from mismanagement in the year 2017, Rs. 100/- was collected for registration to each household in the form of acknowledgement of community ownership and was to the village headman and village authority. Since this village is administrated under his chieftainship, the headman has a final say on this community land. In the case of individual land is prevailing in some of the villages, in this type of landholding system, the so-called the clan and the Headman have no say related to selling the land, for example, whom to sell the land? when to cultivate and which site he should do farming, collecting wood, and do shifting cultivation? All these are decided according to the will of the concerned individual. However, selling his land to someone outside the village is prohibited. ${ }^{23}$

One third of this entire land is owned by private and clan owners in such a situation that a limited size of arable land has affected the village agricultural activities. Most of the abandoned land suitable for cultivation was left unutilized for several years. As one of the villagers rightly said, "they cannot do anything since their ancestors have not left enough land for farming or shifting cultivation. Today, they have to beg, running from pillar to post to make it sure that they can produce food sufficient for a year." The landowners are less concerned about people. Instead, they are proud of owning a big size of land without caring for the welfare of this poorer section, who do not have enough land for cultivation in this village. This is how the pattern of landholding system had affected the agrarian community. ${ }^{25}$

\subsection{Proposed Land Reform Policy in the Hills of Tangkhul Community}

Hills Area Committee (HAC) is given total empowerment to administer the hilly areas according to the constitutional Act of Parliament of India passed in1972. Without HAC consent, Manipur government is not empowered to do anything. One of the respondents said, "how Hills Area Committee became weak is that Chief Minister appoints only yes man of HAC members on personal favours." The land ownership is based on private or individual and the patta system. For example, in Churachandpur, since this act has become functional, the government started surveying the villages. All of these concepts rooted in the 'hill' by the government are based on

\footnotetext{
${ }^{23}$ Interview conducted on February 7, 2019

${ }^{24}$ Interview conducted on Marchr 26, 2019

${ }^{25}$ Interview conducted on February 7, 2019
} 
the geographical area only. The tribal community interpretation of 'hill' has a political connotation. $^{26}$

There is a proposal concerning land distribution in the form of liberalization based on two points. One is the land consolidation programme, which aims at the efficient land use within a village with a demarcation of land for cultivation. Secondly, the appropriate implementation of the Land Acquisition mechanism. In cases, where acquiring prime agricultural land becomes inevitable, a chance for developing an equal extent of wasteland should be given in the form of compensation. However, the programme has its own setback in spite of the best efforts given (Sinha \& Pushpendra, 2000). This situation may be different in the case that the tribal community (Tangkhul) in which seventy per cent of land grappled in the hands of few people among the community needs to be released in the form of selling to the immediate members of the village to have positive agricultural production outcomes in the village. Such concrete arrangement should be worked out just as like the land reform initiated in India, though it is different from this community.

One of the well- known intellectuals ${ }^{27}$ among the Tangkhul Nagas has proposed a new land distribution system to suit the agrarian change in this community: Each household should have a place called "village compound" where this provided place should accommodate those who are intending to have a separate household after getting married. The proposal was submitted in the Guwahati High Court. This land survey was done without any approval from the concerned authorities and has made it difficult to trace the misplaced documents. The proposed landholding system that has come out as a result of interactions or interviews is highlighted here: (i) The land should be properly registered in the state government, (ii) the land should be entirely handed over to the village Chief or Headman, (iii) land patta registration should be under the village councils or village authorities, (iv) this idea of the proposal is to preserve and protect the individual or the clan or the village property and to manage in a right way, (v) forest or reserve law is made by the state government without the proper knowledge of the tribal people in Manipur, (vi) the Manipur forest law was made in such a way that when the hilly people cannot raise their objection when the state government wants to implement the developmental project, (vii) it is through this proposed system the state government should take prior permission or take the consent of the villager for the purpose of utilisation. No land and forest laws should prevail in this place which is not different from khas land (horkahai ngalei) in the valley.

One day, similarly, like in other parts of India and the other counties in Ukhrul district, which is inhabited by the Tangkhul Nagas, land can be encroached upon by any agencies. Since the land laws are not stringently protected and enforced by the state government under the article 371C. Land laws should be totally in the hands of the village authority with regard to registration, allotment, etc. Nagas has a very rigid landholding system while Kuki has a very loose landholding system. In addition to the existing land laws in support of developing more concrete land laws for the hills of Nagas in Manipur one of the respondents, supplemented his willingness recollecting how Ambedkar has pursued the government of India to protect the tribal lands in

\footnotetext{
${ }^{26}$ Interview conducted on September 2, 2018

${ }^{27}$ Interview conducted on October 18, 2016
} 
India as a result of which tribal lands in India is safeguarded or remain protected despite several cases of encroachment and infringement under the constitution of India. ${ }^{28}$

Another proposal made by him is that all the Tangkhul villages should send a representative to the Tangkhul Naga Long (TNL) which is the apex body. This is how village land records could be maintained. As the Tangkhul customary law binding on land says, "Village land should remain under the chief or headman, under him, there is a head of the clan (shangwui pipa)." The village chief or the headman should not influence or have said in the case of the clan's and individual's lands according to the Tangkhul landholding system. The land cannot be forcibly touched upon by the headman of the village chief other than the community or the village land. Such mechanisms have been protecting the people and their land rights until now. Even though, the presence of such uniqueness of ownership rights are not recognized by the state government of Manipur practically. In other words, the government of Manipur did not accept this as a recognized land laws and thus the land laws made for the hills exist in a loose manner. Therefore, he emphasised the need to work out a possibility of legal recognition by the state government. This proposed land would in a way recognize only the village or the community lands. The example of the legality of land issue, being faced in Assam, can be one of the eyes-opening to encourage why legal status is required. When the tea plantations were ultimately established in Assam, there were land disputes between the Nagas and the colonised provinces of Assam, resulting in redrawing the boundary several times and found loopholes in safeguarding the land by the concerned authorities. ${ }^{29}$

\section{Conclusion}

It is difficult to develop a uniform landholding system due to the nature of existing conditions of landscapes; some lands are rocky, some are fertile, some are not fertile, whereas, there is only one type of landholding system in the valley. In the hills, there is a criterion of classifications of land that cannot be done exactly like the valley. The existing land ownership rights of different parties, be it a private or individual, clan and community in one way, have determined the kind of agrarian changes that is taking place in the Tangkhul community. This is how the landholding system, in the process of modernization and the advent of Christianity has impacted the agrarian structure.

The intactness of the existing landholding system determines agrarian changes. For example, you cannot do farming in a land that belongs to the individual and clan. In such a situation, even the Headman or the Chief of the village, cannot have a say as the ultimate authority lies in the hands of the concerned individuals and the clan. All these existing customary practices concerning land in several ways have affected the healthy growth in the production of agriculture. The key to raising productivity in agriculture lies largely in the deregulation of the policy and equitable distribution of landholdings which, in turn, would enhance the growth in the production.

\footnotetext{
${ }^{28}$ Interview conducted on October 18, 2016

${ }^{29}$ Interview conducted on October 18, 2016
} 


\section{References}

[1] Binodini Devi, P. (2006). Tribal land system of Manipur. Akansha Publishing House.

[2] Datye, V. S. \& Diddee, J. (1981). Microanalysis of landholdings and agricultural practices: Case studies (Pune). Transactions of the Institute of Indian Geographers, $3(1), 89-99$.

[3] Deininger, K. (2003). Land policy for growth and poverty reduction. World Bank and Oxford University Press.

[4] Ghosh, S.K. (1987). Law enforcement in tribal areas. Ashish Publishing House.

[5] Gangmumei, K. (1985). Anal: A transborder tribe of Manipur. Mittal Publication.

[6] Gangmumei, K. (1986). The land system of the Rongmei tribe of Manipur [Unpublished manuscript]. Department of History, Manipur University.

[7] Malinowski, B. (1965). Coral Gardens and their Magic. Indian University Press.

[8] Mitra, A. (1953). An account of Land reform in West Bengal 1850-1950, Alipore: Government Press.

[9] Morris, D., \& Marsh, P. (1988). Tribes. Pyramid.

[10] National Sample Survey Organisation. (1999). Common property resources in India. (No.452). Department of Statistics. Doi-ind-mospi-nsso-54 rnd-sch31-Jan1998-June $19 \mathrm{TH}$.

[11] Russett, M. B. (1964). Inequality and instability: The relation of land tenure to politics. World Politics, 16(3), 442-454. doi:10.230712009581

[12] Ruivah, K. (1987). Land ownership and its problems among the Tangkhul Naga. In Dutta, B.B. \& Karna, M.N. (Eds.), Land relations in North-East India (pp.54-64). New Delhi.

[13] Shimray, U.A. (2007). Ecology and economic system: A case study of the Naga community. Regency Publication.

[14] Sikidar, S. (1990). Economic of Tribal India. Delhi: Ashish Publishing House. Regency publication.

[15] Sinha, B. K. and Pushpendra, K., (2000). Land reform in India: An unfinished agenda. Sage Publication.

[16] Smith Lynn, T. (1967). Social structure and the process of development. University of Florida Publications

[17] Tiwari, B. K. \& Shahi, K. (1995). Land ownership pattern in Meghalaya. In Tiwari, B. K. \& Singh, S. (Eds.), Ecorestoration of degraded Hills (pp.61-78). Kaushal Publication. 